\title{
Reproductive performance and embriotoxicity of rats exposed to carbamazepine
}

\author{
Marli Gerenutti*, Carolina Clavijos de Oliveira, Aliana Conceição Ribeiro de Miranda, \\ Raquel Mendonça Rosa, Fernando de Sá Del Fiol
}

Curso de Farmácia, Universidade de Sorocaba

*Correspondência:

M.Gerenutti,

Universidade de Sorocaba

Av. Dr. Eugênio Salerno, 140

18035-430 - Sorocaba - SP, Brasil

E-mail marli.gerenutti@uniso.br.
To study the possible effects of carbamazepine in rats during pregnancy and fetuses' physical development, carbamazepine solubilized in propilenglycol was orally administered (20 and $40 \mathrm{mg} / \mathrm{kg}$ ) to the female rats from the $2 \mathrm{nd}$ to the $19 \mathrm{th}$ days of pregnancy. Propilenglycol was administered to the control group. The animals were sacrificed on the 20th day, when $50 \%$ of the offspring were fixed in Bouin's solution and the remaining 50\% were submitted to diaphanization. The carbamazepine administration caused reduction on weight gain of pregnant rats and did not damage the females' reproductive performance. In the fetuses' physical development, it was observed a flattening on the skull soft tissues and bones; delay in the skull bone development; cartilage calcification increase between hip and femur and reduction in the number of the sternum ossifications. Although carbamazepine has not caused general changes over female rats' reproductive performance, it produced significant alterations in the development of the fetuses' skeletal parameters.
Uniterms

- Carbamazepine

- Teratology

- Embriotoxicity

- Pregnancy

- Reproduction

\section{INTRODUCTION}

Drugs usage during pregnancy and breast feeding demands a critical evaluation regarding exposure period, dosage, therapy term and fetal and neonatal susceptibility (Del Fiol et al., 2005; Iqbal et al., 2001; Mantovani, Calamandrei, 2001; Gerenutti et al., 1991).

Two profiles of medicamental exposure of pregnant females require special attention: the self-medication and the exposure due to chronic pathologies. As for the selfmedication, it has been observed that the intervention is more effective when the prenatal attendance is made. However, in polytherapy - a common practice among carriers of chronic pathologies - special attention is given to antipsychotic and antiepileptic drugs, which may induce to anatomical and/or biochemical abnormalities specially when specifying a group of epileptic pregnant females (Kaneko et al., 2001; Samren et al., 2003).

The arising of several new options for epilepsy treatment during the last decade is promoting a more flexible and individualized approximation to patients (Wheless, Venkataraman, 1999; McCabe, 2000).

The pharmacokinetic of these drugs, in general, determine their ability to maintain concentrations that maximize their efficiency and safety (Azarbayjani, Danielsson, 1998). The pharmacokinetic properties of the antiepileptic, generally include availability of parenteral formulation, satisfactory elimination halflife for one or two daily dosages, linear elimination kinetic, no enzymatic selfinduction and absence of pharmacokinetic interaction with 
another drugs (Bourgeois, 2000).

The antiepileptic drugs still considered as the most efficient ones are carbamazepine and valproic acid. Although these drugs have shown teratogenic effect in humans, many times this effect has been laid to genetic factors, associated with the pathology itself. Offspring born to mothers with epilepsy are subject to a double risk, that is, to both epilepsy and antiepileptic drugs. The effects of neonatal direct toxicity and a high potential for behavior sequelae, related to language and learning capacity, are added to the teratogenic effects resulting from the antiepileptic drugs exposure during pregnancy (Adab et al., 2001; Azarbayjani, Danielsson, 1998; Gaily et al., 1996).

Although the highest index of malformation in children born to mothers with epilepsy is associated to the mother exposure to antiepileptic drugs (AED), the interruption of the treatment may allow the convulsive fits and consequent fetal risks due to intrauterine hypoxia (Kaaja et al., 2004).

This work's objective is to study the possible effects of the carbamazepine administration over the reproductive performance of female rats and also the evaluation of its effects on the fetuses' morphological parameters.

\section{MATERIAL AND METHODS}

\section{Animals}

The animals usage in this experiment was rigorously approved by the Sorocaba University Committee for Ethic in Research. Male and female Wistar rats used were of the same lineage, age ranging between 3 to 4 months, weighting between 160 to $200 \mathrm{~g}$.

\section{Pregnancy test}

For the coupling, 2 males and 5 females were lodged during a 12-hour night period, in plastic cages with metallic covers, measuring $40 \times 50 \times 20 \mathrm{~cm}$. By means of microscopical observation, the indicative of the first pregnancy day was the existence or not of spermatozoids in the smear taken from a vaginal washing (Vickery, Bennett, 1970).

\section{Reproductive ability evaluation}

The pregnant animals were divided into three groups of ten and lodged in a number of five per cage. In the twentieth pregnancy day, the animals were sacrificed; the ovaries were removed for subsequent counting of corpi luteum and the womb was taken off for fetuses and placenta removal, the fetuses' vitality was also observed (Lemonica et al., 1996). The fetuses were randomly divided into two groups; the average number of fetuses of each group was fixed in Bouin's solution, for further macroscopic analyses. The following measurements were taken with a pachymeter: skull anteroposterior, skul latero-lateral, thorax antero-posterior, thorax latero-lateral, cranio-caudal, tail (Sterz, Lehmann, 1985; Barrow, Taylor, 1969). A process of evisceration and diaphanization was realized for bone study (Dawson, 1926).

Females fertility rate was calculated by means of the following formulae: Pre-implantation Losses $=$ number of corpi luteum - number of implantations/number of corpi luteum and Post-implantation Losses $=$ number of implantations - number of alive fetuses/number of implantations.

\section{Drugs and administration route}

Two groups were exposed to carbamazepine (batch 01010419, Galena Quality Control Laboratory) solubilized in propyleneglycol $\left(16^{\circ} \mathrm{C}\right)$ in the dosages of 20 and $40 \mathrm{mg} /$ $\mathrm{kg}$, respectively. The administered dosages were similar to those therapeutically used. (Bauer et al., 2002; Williams et al., 2001). Propyleneglycol was administered to the control group. The daily administration of the drug was orally made, from the first to the tenth pregnancy days, always at 4:00 p.m.. Water and food were supplied ad libitum during all the experiment. The animals weight was daily followed up.

\section{Statistical analysis}

The results underwent statistical analyses, when the critical significance level accepted for rejection of the invalidity hypotesis, had a probability up to $5 \%(\mathrm{p} \leq 0.05)$ in all the applied analyses. The Tukey-Kramer Test was used for comparing the averages between experimental and control groups, considering the animals weight gain, the female rats reproductive performance (weights of placentas and fetuses) and offspring external morphological parameters. Qui-square Test was used to evaluate the changes, measured in percentage, including the osseous development parameters, pre-implantation losses, postimplantation losses and fetuses' vitality.

\section{RESULTS}

\section{Evaluation of female rats weight gain when exposed to carbamazepine during pregnancy}

The results indicate that carbamazepine administration during pregnancy, in the dosage of 20 and 


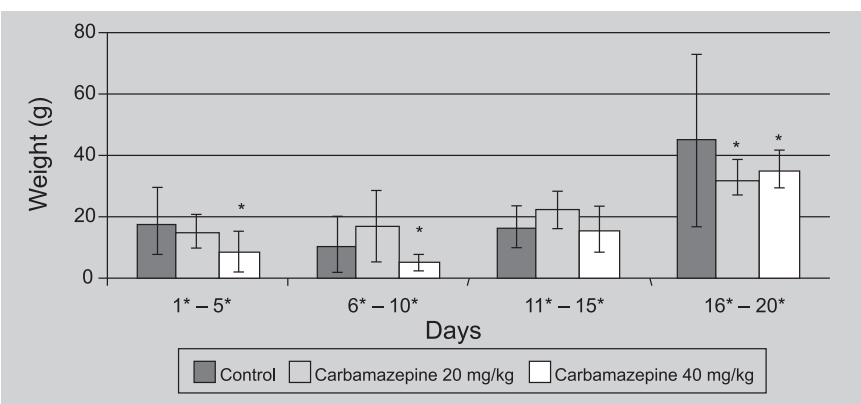

FIGURE 1. Effects of carbamazepine on weight gain of pregnant rats. Data are reported as mean \pm S.E.M. ${ }^{*} p<0.05$, Tukey-Kramer Test, 10 animals per group.

$40 \mathrm{mg} / \mathrm{kg}$ reduced weight gain in pregnant rats (Figure 1).

\section{Reproductive performance evaluation of female rats exposed to carbamazepine during pregnancy}

The administration of carbamazepine during pregnancy, in the dosage of 20 and $40 \mathrm{mg} / \mathrm{kg}$, has not significantly changed the percentage of pre-implantation and post-implantation losses, as well as has not occasioned changes to the placenta, nor to fetuses' weight and vitality.

TABLE I - Effects of carbamazepine on fetuses' sternum ossification

\begin{tabular}{lccc}
\hline $\begin{array}{l}\text { Number of } \\
\text { Sternum } \\
\text { Ossifications }\end{array}$ & Control & $\begin{array}{c}\text { Carbamazepine } \\
20 \mathrm{mg} / \mathrm{kg}\end{array}$ & $\begin{array}{c}\text { Carbamazepine } \\
40 \mathrm{mg} / \mathrm{kg}\end{array}$ \\
\hline 0 & 4.1 & $10.5 *$ & $7.8^{*}$ \\
1 & 10.2 & 5.3 & $19.6^{*}$ \\
2 & 14.3 & $5.3 *$ & $35.3^{*}$ \\
3 & 34.7 & 42.1 & $21.6^{*}$ \\
4 & 36.7 & 36.8 & $15.7^{*}$ \\
\hline
\end{tabular}

Data are reported in percentage.

$* \mathrm{p}<0.05$ (Chi-square test), 50 animals per group.

\section{Evaluation of the effects of carbamazepine administration during pregnancy, over the morphological parameters of fetuses}

Analysis of the external morphological parameters of the fetuses fixed in Bouin's solution

The carbamazepine administration in the dosage of 20 and $40 \mathrm{mg} / \mathrm{kg}$, during rats pregnancy period, has not occasioned significant alteration in the external measures of the morphological parameters of the fetuses. It must be taken into consideration the absence of sindactily and cleft palate and also that no alteration related to eyes and ears implantation was evidenced.

\section{Analysis of the diaphanized fetuses' skeletal structure}

Table I indicates that carbamazepine in the dosage of $40 \mathrm{mg} / \mathrm{kg}$ occasioned a significant anticipation of the sternum ossification in fetuses.

Table II shows it clearly that carbamazepine, when administered during rats pregnancy period, in the dosages of 20 and $40 \mathrm{mg} / \mathrm{kg}$, caused a flattening on the skull soft tissues and bones; cartilage calcification increase between hip and femur, and, in the dosage of $40 \mathrm{mg} / \mathrm{kg}$, caused delay in the skull bone development.

\section{DISCUSSION}

Many of the changes observed during birth, growth and development are due specially to the mother's exposure to chemical agents (Gerenutti et al., 2006; Mantovani, Calamandrei, 2001). Antiepileptic drugs like carbamazepine, phenytoin, trimethadione and phenobarbital have been constantly associated to a malformation pattern and to delays in growth and development. The alterations noticed during uterus exposition to these drugs support the idea that adverse effects on fetus are started by a simple pharmacologic mechanism: blockage of ion channels in the heart of the growing embryo, which results in bradycadia,

TABLE II - Effects of carbamazepine on fetuses' osseous structure

Osseous structure of fetuses

Parameters Control Carbamazepine $20 \mathrm{mg} / \mathrm{kg} \quad$ Carbamazepine $40 \mathrm{mg} / \mathrm{kg}$

\begin{tabular}{lrrr}
\hline Flattening on the skull soft tissues and bones & 2.0 & $15.8 *$ & $29.4 *$ \\
Cartilage calcification between hip and femur & 14.3 & $50 *$ & $41.2 *$ \\
Delay in the skull bone development & 4.1 & 5.3 & $17.6^{*}$
\end{tabular}

Data are reported in percentage.

$* \mathrm{p}<0.05$ (Chi-square test), 50 animals per group. 
hemodynamic alterations, hypoxia and reoxygenation (Azarbayjani, Danielsson, 1998).

In the current work, carbamazepine effects over fetal morbidity and death rate, as well as the probable alteration in their development were evaluated when this drug is administered in the dosages of 20 and $40 \mathrm{mg} / \mathrm{kg}$ in female rats, during pregnancy period. In studies of such a nature, it is important to dissociate the existence of toxic effects on the mother, because this on its own might cause alteration in the conceptus development (Manson, Kang, 1994).

Although significant weight gain reduction in pregnant rats has been observed under the used dosages, it was neither observed alteration in the locomotor activity (data not show), nor bristly fur, parameters indicative of toxicity and physical discomfort of the animals, as well as no mother deaths were observed.

The motherly reproductive performance is a very important parameter for the analysis of perinatal toxicity of drugs (Lemonica et al., 1996). Thus, considering that corpi luteum are the main source for progesterone secretion (Kato et al., 1979) - and it has already been showed that their growth are deeply related to the increase in the progesterone and 20-hydroxyprogesterone secretion - the corpi luteum analysis is of deep importance in experiments where reproductive performance is evaluated (Waynforth, 1971). Our results indicate that, although a small reduction in the average number of corpi luteum of the groups exposed to carbamazepine in the dosages of 20 and $40 \mathrm{mg} / \mathrm{kg}$ were observed, there were no significant alteration when compared to control group.

In the existence of a correlation between the number of corpi luteum and the number of ovulations, it is usual that the first one also be correlated to the number of embryonal implantations, because, in each ovulation an ovocite that can be fecundated is released and turn into a pre-embryo (Ortiz et al., 1979). The rate of preimplantation losses establishes the relation between two variables, number of corpi luteum and number of implantations. Our data indicate the administration of carbamazepine in the dosages of 20 and $40 \mathrm{mg} / \mathrm{kg}$ has not modified the rate of pre-implantation losses.

Christensen et al. (2004), in studies performed in mice, assures that carbamazepine does not present effects on the reproductive performance of females. The results achieved in this present work also indicate that carbamazepine, in the dosages of 20 and $40 \mathrm{mg} / \mathrm{kg}$, does not present effects on the female rats reproductive performance, because it can be verified that parameters as: rates of post-implantation losses, weight of placenta, fetuses's weight, as well as, offspring vitality, were not modified by the exposure to carbamazepine.
Modifications in the parameters of the fetuses physical development, such as antero-posterior and laterolateral measures of the skull, antero-posterior and laterolateral measures of the thorax, ears and eyes implantation, members alteration and cleft palate were not evidenced. Therefore carbamazepine in the dosages of 20 and $40 \mathrm{mg} / \mathrm{kg}$ generated cartilage calcification increase between hip and femur and under the dosage of $40 \mathrm{mg} / \mathrm{kg}$ generated a significant advance of the fetuses' sternum ossification, such data actually confirm the evidence of malformations when there is an exposure to carbamazepine (Canger et al., 2001; Jick, Terris, 2002). The fetus embriotoxicity alterations observed did not have nutritional origins, because weigh fetus and placenta alterations were not found when control and experimental groups were compared.

The results show that the exposure of pregnant rats to carbamazepine generate significant alteration, as skull and soft tissues flattening and delay in the skull bone development. However, these alterations seem neither result in changes related to the behaviour parameters of the offspring (Christensen et al., 2004; Rayburn et al., 2000), nor contribute to the alterations in the children's intelligence when exposed to the drug during fetal term (Gaily et al., 1996).

From the data of this study we can conclude that, although carbamazepine has not promoted general alteration over the rats reproductive performance, it has promoted significant alteration in the skeletal parameters of fetuses.

\section{RESUMO}

\section{Performance reprodutiva e embriotoxicidade de ratos expostos à carbamazepina}

Este trabalho teve como objetivo estudar os possiveis efeitos da administração da carbamazepina na gestação de ratas. A solução glicólica de carbamazepina foi administrada por via oral $(20 \mathrm{mg} / \mathrm{kg}$ e $40 \mathrm{mg} / \mathrm{kg})$, às ratas do $2^{\circ}$ ao $19^{\circ}$ dia de gestação. O grupo controle recebeu solução de propilenoglicol. Após a realização da cesária, no $20^{\circ}$ dia, $50 \%$ dos filhotes foram fixados em Bouin e os outros $50 \%$ passaram por processo de diafanização. Estes estudos mostraram que embora a administração de carbamazepina tenha promovido redução do ganho de peso de ratas prenhes, não prejudicou a performance reprodutiva de fêmeas. Nos fetos, observou-se achatamento de tecidos moles e ossos do crânio, retardo no desenvolvimento ósseo do crânio, aumento da calcificação da cartilagem entre o quadril e o fêmur e redução no número de ossificações do esterno. Estes dados, tomados em conjunto, indicam que a adminis- 
tração de carbamazepina não promoveu alterações gerais sobre a performance reprodutiva de ratas, entretanto promoveu alterações significativas nos parâmetros de desenvolvimento esquelético de fetos.

UNITERMOS: Carbamazepina. Teratologia. Embriotoxicidade. Reprodução.

\section{REFERENCES}

ADAB, N.; JACOBY, A.; SMITH D.; CHADWICK, D. Neurosurgery and Psychiatry. J. Neurol., v.70, n. 1, p.15, 2001.

AZARBAYJANI, F.; DANIELSSON. B.R. Pharmacologically induced embryonic dysrhythmia and episodes of hypoxia followed by reoxygenation: a common teratogenic mechanism for antiepileptic drugs? Teratology, v. 57, n.3, p.117-126,1998.

BARROW, M.V. TAYLOR, W.J. A rapid method for detecting malformations in rat fetuses. J. Morphol., v.127, n.3, p.291-306, 1969.

BAUER, J.;HERMANN, A.; REUBER, M. Tolerance of high dosage carbamazepine monotherapy in treatment of epilepsy. Nervenarzt, v.73, n.6, p.533-537, 2002.

BOURGEOIS, B.F. Pharmacokinetic properties of current antiepileptic drugs: what improvements are needed? Neurology, v.55, n.11 (suppl. 3), s.11-16, 2000.

CANGER, R.; BATTINO, D.; CANAVINI, M.P.; FUMAROLA, C.; GUIDOLIN, L.; VIGNOLI, A.; MAMOLI D. Malformations in offspring of women with epilepsy: a prospective study. N. Eng. J. Med., v.344, n.15, p.1132-8, 2001.

CHRISTENSEN, H.D.; RAYBURN, W.F.; PARKER, K.M.; GONZALEZ, C.L.; GOLD, K.P. Chronic prenatal exposure to carbamazepine and perinatal outcomes of C3H/He mice. Am. J. Obstet. Gynecol., v.190, n.2, p.51721, 2004.

DAWSON, A.B. Note on the staining of skeleton of cleared skeletal specimens with alizarin red S. Stain. Technology, v.1, p.123-124, 1926.
DEL FIOL, F.; GERENUTTI, M.; GROPPO, F.C. Antibiotics and pregnancy. Pharmazie, v.60, n.7, p.483493, 2005.

GAILY E, KANTOLA-SORSA E, HIILESMAA V, ISOAHO M, MATILA R, KOTILA M. Normal intelligence in children with prenatal exposure to carbamazepine. Zentralbl Gynakol , v.1, n.18 (suppl. 3), p.169-171, 1996.

GERENUTTI, M.; DEL FIOL, F.; GROPPO, F.C. Reproductive performance of pregnant rats and embryotoxic effects of ciprofloxacin. Pharmazie, v.61, n.1, p.79-80, 2006.

GERENUTTI, M.; DE-SOUZA SPINOSA, H.; BERNARD, M.M. Algumas considerações sobre a toxicologia do desenvolvimento. Comunicações Científicas da Faculdade de Medicina Veterinária e Zootecnia da Universidade de São Paulo, v.1, p.27-29, 1991.

IQBAL, M.M.; SOHHAN, T.; MAHMUD, S.Z. The effects of lithium, valproic acid, and carbamazepine during pregnancy and lactation. J. Toxicol. Clin. Toxicol., v.39, n.4, p.381-392, 2001.

JICK, S.S.; TERRIS, B.Z. Anticonvulsants and congenital malformations. Reprod. Toxicol..v. 16, n.1,p.9-17, 2002.

KAAJA, E.; KAAJA, R.; HIILESMAA, V. Major malformations in offspring of women with epilepsy. Neurology, v.62, n.1, p.28-32, 2004.

KANEKO, S.; OTANI, K.; KONDO, T.; FUKUSHIMA, Y.; NAKAMURA, Y.; OGAWA, Y. et al. Malformation in infants of the mothers with epilepsy receiving antiepileptic drus. Neurology, v.57, n.2, p.321-324, 2001.

KATO, H.; MORISHIGE, W.K.; ROTCHILD, I. A quantitative relationship between the experimentally determined number of conceptuses and corpus luteus activity in pregnant rats. Endocrinology, v.105, n.3, p.846-850, 1979.

LEMONICA, I.P.; DAMASCENO, D.C.; DI-STASI, L.C. Study of the embryotoxic effects of an extract of rosemary (Rosmarinus officinalis L.). Braz. J. Med. Biol. Res., v.29, n.2, p.223-227, 1996. 
MANSON, J.M.; KANG, Y.J. Test methods for assessing female reproductive and developmental toxicology. In: HAYES, A.W., (Eds.). Principles and methods of toxicology. New York: Raven Press, 1994. p. 989-1037.

MANTOVANI, A.; CALAMANDREI, G. Delayed developmental effects following prenatal exposure to drugs. Curr. Pharm. Des.,v.7, n.9, p.859-880, 2001.

MCCABE, P.H. New anti-epileptic drugs for the 21 st century. Expert Opin. Pharmacother., v.1, n.4, p.633-674, 2000.

ORTIZ, M.E.; VILLALÓN, M.; CROXATTO, H.B. Ovum transport and fertility following post ovulatory treatment with estradiol in rats. Biol. Reprod., v. 21, n.5, p.11631167, 1979.

RAYBURN, W.F.; GONZALEZ, C.L.; PARKER, K.M.; CHRISTENSEN, H.D. Chronic prenatal exposure to carbamazepine and behavior effects on mice offspring. Neurotoxicol. Teratol., v.22, n.5, p.733-739, 2000.

SAMREN, E.B.; VAN DUIJN, C.M.; CHRISTIAENS, G.C.; HOFMAN, A.; LINDHOUT, D. Antiepileptic drug regimens and major congenital abnormalities in the offspring. Epilepsy Behav., v. 4, n.4, p.447-448, 2003.
STERZ, H.; LEHMANN, H. A critical comparison of the freehand razor-blade dessection method acoording to Wilson with an in-situ sectioning method for the rat fetuses. Teratog. Carcinog. Mutag., v. 5, n.5, p.347-354, 1985.

VICKERY, B.H.; BENNETT, J.P. Rats and mice. In: HAFEZ, E.S.E., (Ed.). Reproduction and beeding techniques for laboratory animals. Philadelphia: Lea and Febiger, 1970. p. 299-315.

WAYNFORTH, H.B. Changes in the volume of rat corpus luteum during pregnancy and after surgical interference with the uterus and placenta. Acta Endocrinol., v.66, p.296-302, 1971.

WHELESS, J.W.; VENKATARAMAN, V. New formulations of drugs in epilepsy. Expert Opin. Pharmacother., v.1, n.1, p.49-60,1999.

WILLIAMS, J.; PATSALOS, P.N.; MEI, Z.; SCHAPEL, G.; WILSON, J.F.; RICHENS, A. Relation between dosage of carbamazepine and concentration in hair and plasma samples from a compliant impatient epileptic population. Ther. Drug Monit., v. 23, n.1, p.15-20, 2001.

Recebido para publicação em 06 de fevereiro de 2006 Aceito para publicação em 29 de janeiro de 2008 